\title{
旭川市平和通買物公園のマネジメントの変遷に関する研究 TRANSITION OF MANAGEMENT OF HEIWA MALL IN ASAHIKAWA CITY
}

\author{
三浦詩乃*, 出口＼cjkstart敦**
}

\section{Shino MIURA and Atsushi DEGUCHI}

\begin{abstract}
Pedestrianizing a street has been recognized as a useful planning method to vitalize the activities in a downtown. This paper focuses on the management system for Heiwa Mall located in the downtown of Asahikawa City, which was pedestrianized in 1972 as the first pedestrianized public street in Japan. It clarifies the process of forming the existing management system since then and points out the characteristics and problems of the long term management. It concludes by suggesting the key factors considered for the management system for a pedestrianized street.
\end{abstract}

Keywords : Pedestrian mall, Street, City center, Vitalization, Asahikawa City 歩行者専用道路, 街路, 中心市街地, 活性化, 旭川市

\section{1.はじめに}

\section{1-1 背景}

中心市街地における毎日及び終日の恒久的歩行者専用道路は、モ ータリゼーションに伴い悪化した都心部の交通問題及び大気污染等 の環境問題の改善を目的に多くの都市で導入が進められてきた。

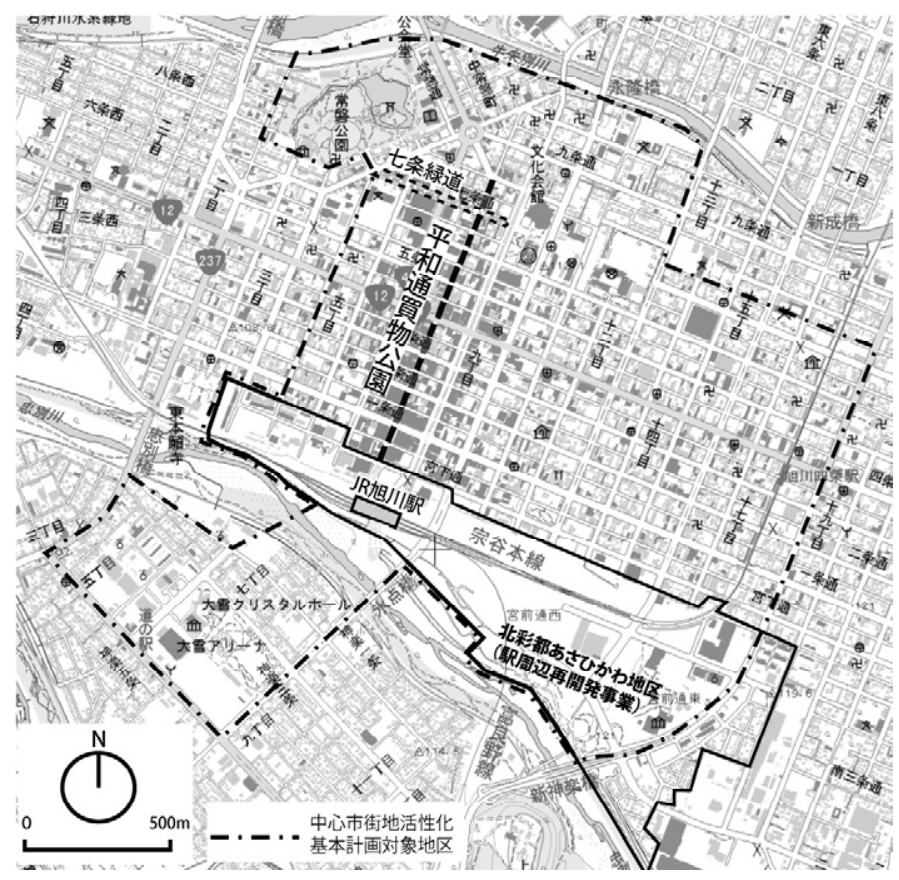

図 1 旭川市中心市街地における平和通買物公園の位置注1)
先駆的な事例として、いずれも 1972 年に完成したドイツ・ミュン ヘン市、ブラジル・クリチバ市と共に、本研究の対象である旭川市 都心部における平和通買物公園が挙げられ、平和通買物公園は日本 でいち早く恒久的歩行者専用化に取り組んだ事例として知られてい る。都心部の歩行者専用道路の充実化は、今日でも国際的な都市交 通計画の中心的課題となっている ${ }^{1)}$

また近年では、高齢社会の到来や中心市街地の空洞化の問題に関 連し、都心の魅力向上に寄与する回遊性と賑わいを創出する方策と して道路の歩行者専用化や歩行者空間としての利活用が注目されて いる。例えば日本では、国土交通省が 2005 年度に「地域の活性化 等に資する路上イベントに伴う道路占用許可基準」を制定し、2011 年度には都市再生特別措置法の拡充を通じて、道路の民間活用を支 援している。こうした制度を活用した歩行者専用道路の整備や利活 用が、自治体を中心にして今後も進むと思われるが、歩行者専用道 路の整備や管理運営を地元で持続的に担っていくことがその成功の 鍵を握っているとも言える。

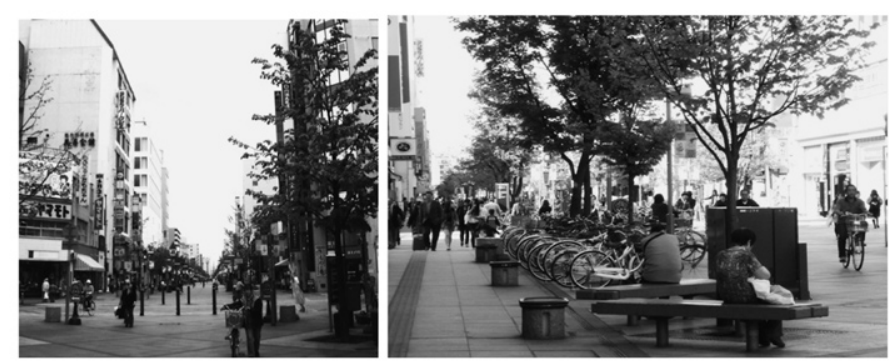

図 2 平和通買物公園の現況

$*$ 東京大学大学院新領域創成科学研究科 博士課程 $\cdot$ 環境修 *** 東京大学大学院新領域創成科学研究科 教授. 工博

Doctor Candidate, Graduate School of Frontier Science, The University of Tokyo, M. Env. Prof., Graduate School of Frontier Science, The University of Tokyo, Dr. Eng. 


\section{1-2 研究の対象}

本研究で対象とする平和通買物公園（以下、買物公園）は、JR 旭川駅を起点に南北にのびる目抜き通りであると共に、全長約 $1,050 \mathrm{~m}$ 、幅員約 $20 \mathrm{~m}$ 、路面総面積約 21 万 $\mathrm{m}^{2}$ の日本初の恒久的歩行 者専用道路である(図 1)。歩行者専用化の計画に基づき 1972 年に整 備され、沿道には商業を中心とする民間施設が立地している(図 2)。

一般に「マネジメント」の用語は、施設、公園、道路等の整備後 の管理・運営、もしくは計画や設計プロセスの運営を指すが、我が 国初の歩行者専用道路である買物公園の計画段階から現在に至る一 連の過程を体系的に整理し、今後の歩行者空間整備に活かしていく ことを目的とする本研究では、マネジメントの用語を、(1)歩行者専 用化の初期段階の計画、(2)歩行者専用道路と商業施設を含む沿道空 間の整備及び再整備、(3)その維持管理及び活用、に係る組織的取り 組みを示す概念として使用する。

\section{1-3 目的と方法}

上述の背景の下、本研究では、買物公園を対象に約 40 年間にわ たるマネジメントの変遷を整理すると共に、社会情勢の変化との対 応関係からみたマネジメントの課題を明らかにする。更に、買物公 園のマネジメントの整理により得られた知見から一般的な歩行者専 用道路のマネジメントにおける留意点を導き出すことを目的とする。

また、分析の視点として、目抜き通りはその都市を象徴する空間 であり、不特定多数の人々がマネジメントに関与し、比較的大規模 な街路整備が必要となること、また、中心市街地の都市構造におい て重要な街路であることから、(1)多様な主体間の合意形成、(2)資金 を含めた事業計画、(3)土地利用計画・交通計画との関係性の 3 点に 焦点を当て、買物公園のマネジメントの変遷を整理することとした。

研究方法としては、文献調査及びヒアリング調查を行い、買物公 園におけるマネジメントの変遷を時系列に整理した。具体的には、 買物公園の計画に関寸る資料注 2$)$ 、地図資料、新聞記事等を対象と した文献調查を行った。ヒアリング調查は、(1)同市の土地利用計画・ 交通計画については旭川市の行政担当者に、(2)マネジメント体制や 再整備時の経緯については商店街振興組合及び沿道の商店主に、(3) 再整備時の設計等については当時の設計者に対してインタビュー形 式で実施し、調査で得られた内容を「合意形成」「資金を含めた事業 計画」「土地利用計画・交通計画との関係性」の観点から時代区分ご とに整理し、社会情勢の変化との対応関係からみたマネジメントの 課題を考察した。

また、買物公園のマネジメントを整理することを通じて得られた 知見から、歩行者専用道路等のマネジメントの留意点を導出した。

\section{1-4 既往研究}

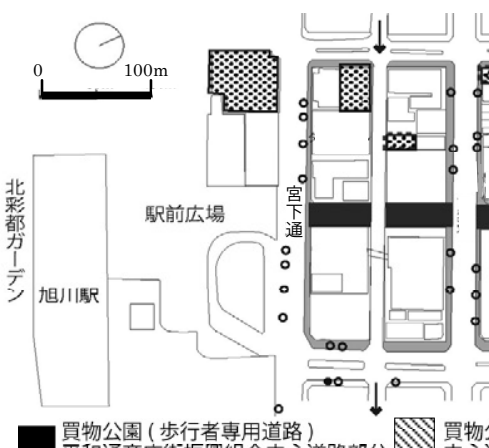
平和通商店街振興組合中心道路)

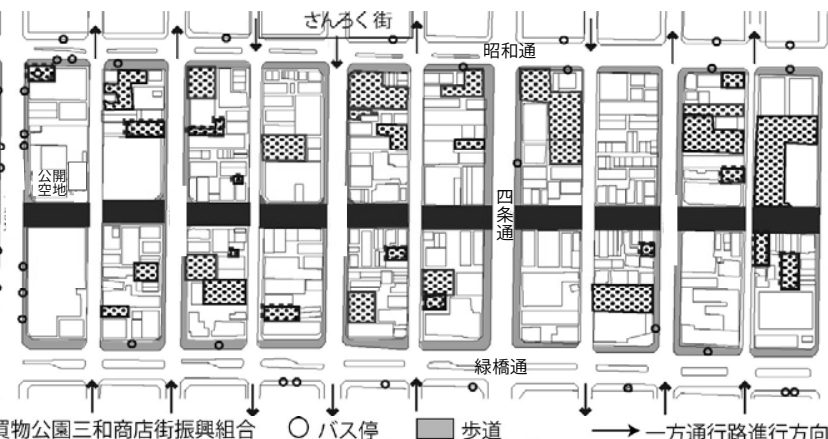

歩道 $\longrightarrow$ 一方通行路進行方向

図 32012 年現在の平和通買物公園と周辺地域の平面図注 4 )
恒久的歩行者専用道路については、Uhlig による代表事例に関す るケーススタディ2)や、Brambilla らによる代表的計画の手法、設 計と運営主体に関する調査 ${ }^{3)}$ 等、70 80 年代に欧米を中心に多数の 研究がなされているが、長期間にわたるマネジメントの方法や仕組 みに関する研究はほとんどみられない。

国内では、交通工学の地区交通の観点から歩行者空間に焦点をあ てた研究 4)や、地理学の観点から歩行者天国の空間管理の動向に注 目した研究 5)、都市計画の観点から歩行者天国における来訪者の行 動分析 6)等がなされている。特に歩行者専用道路については、買物 公園を含む先駆的事例の構想や設計等の記録 778)が整理されている が都市計画の観点から先駆的事例の整備後の実情を再評価する研究 はほとんどない。また、街路のような公共空間のマネジメントに関 する研究では計画及び整備期 9)、もしくは維持管理及び活用期に焦 点をあてたもの 10)が多く、各期を通した研究はほとんど見られない。

買物公園については、石脇らにより空間の変遷や現状の政策の整 理から中心市街地衰退の原因を抽出する研究注3)がなされている。ま た、地理学、土木工学及び経済学の観点から第一期整備当時や現状 の課題を指摘した研究 11)-13) はあるが、長期間にわたるマネジメント の変遷を整理した研究はみられない。

本研究は、我が国初の歩行者専用道路として整備され、今日まで 維持されてきた先駆的事例の長期間にわたるマネジメントを対象に、 恒久的歩行者専用道路のマネジメントの留意点を整理する研究とし ての意義を持つと共に、時系列で整理した希少なデータを提供する 研究としても位置付けられる。

\section{2. 計画の経緯と概要}

1960 年代当時、旭川市は、当時市長であった五十嵐広三氏を中心 に全国にさきがけた都市整備を行っていた自治体の一つであり、 1965 年に『伸びゆく大旭川:まちづくりの方向』14)という長期計画 を策定し、その中で、都心の商業振興と高度利用及び不燃化の誘導 を主な目的とした平和通の歩行者専用化である「買物公園」の構想 が公表された。

また、市長は歩行者専用道路の整備に対して、(1)都心機能を担う、 (2)市民のための広場・人間性のある道路で、(3)市民参画のプロセス を経て、(4)時代変化に対応する維持もしくは整備を行うもの、とし て中心市街地内の重要な公共空間としての位置づけを行った ${ }^{15)}{ }^{16)}$ 。

1972 年、施設帯への植栽やファニチャー設置と恒久的歩行者専用 化が完了し、買物公園の第一期整備が完成した。

買物公園は整備後、わが国の街路整備及び商業近代化整備のモデ ルケースとされ、沿道の商店街（図 3）の売上げ及び通行量は、共

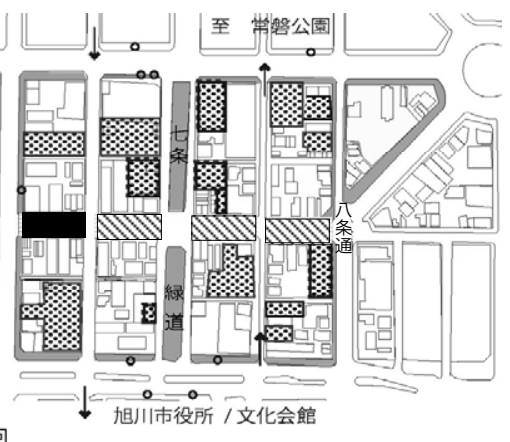


に増加してきたが、近年は通行量が減少し、沿道の空店舗も増加傾 向にある。

\section{3. 計画及び第一期整備期 (1965 72 年) の変遷 3-1 合意形成}

(1)計画期

前述の長期計画が策定された翌年の 1966 年、市は官公庁の担当 者とともに「旭川都市整備委員会」を立ち上げ、同委員会と国土計 画協会に対して、より具体的な買物公園の基本構想策定を委託した。 同時期に、市長の支持母体である青年会議所が、平和通の沿道に立 地する平和通商店街と三和商店街に対して協力要請を行うなど、市 と関連主体とで実現に向けた検討が開始された。

「企画会議」での協議が始まり、平和通における歩行者天国の社 会実験が目標とされた。しかし、当時の道路交通法において車輛通 行禁止は、恒例的な行事と道路の維持修繥のみに認められており、 道路管理者、警察、消防及び陸運関係者らは実験に否定的だった。 そのため企画会議の構成員らはそれらの主体に対する説得に加え、 前述の旭川都市整備委員会と連携しながら、運輸省、警察庁、及び 建設省と交涉し、道路交通法に対処する必要があった。

地道な交涉の後、当時の道路法で占用物件として規定になかった 噴水、花壇、樹木、ベンチ等の仮設も認められ、公園を連想させる 空間構成にて社会実験が実現した。実験は成功し、歩行者専用道路 の恒久化に向けて世論が高まった。

(2)第一期整備期

1970 年、市が国道と道道の各々を、平行する街路へ移管した後、 平和通を市道かつ道路法上の歩行者専用道路とし、1972 年に第一期 整備が完成した。

1971 年の「旭川市都市再開発構想及び平和通買物公園設計に関す る調査研究報告書」注5)に基づいた整備計画は、二期に分けた計画 内容で構成されていた。

第一期整備に続く、官民共働による第二期整備として計画されて いた、再開発、沿道建築物に付設した二階回廊による交差点部の動 線の分断の解決、業務用の集荷センターの設置等を行う総額約 325 億円に及ぶ案は実現に至っていない。

実施設計者は上田篤氏(当時、京都大学助教授)である。その設計 意図は、クロソイド曲線を描く施設帯によるシークエンス景観への 配慮、植栽や休息空間を設けた公園を連想させるデザイン、旭川産 のレンガを用いて地域性を反映することであった。また、計画への 地元の人々の参加を重視し、ファニチャーについて市長と商店街の 意見を取り入れ、彫刻と原色の遊具を混在して配置した ${ }^{7)}$ 。

\section{3-2 資金を含めた事業計画}

1970 年以降、企画会議が「企画委員会」として組織化され、歩行 者専用化の整備のために、商店街による積立を誘導した。第一期整 備の費用分担は表 1 に示寸ように市と商店街で折半した。商店街が 事業主体として新たな設置物を全て市に寄付採納し、市が管理運営 を企画委員会に委託する形をとった。

\section{3-3 土地利用計画・交通計画との関係性}

第一期整備では、歩行者専用化のもたらす自動車交通流への影響 について考慮し、社会実験の際に調査を実施した。その結果、問題 が見られないことが確認できたことから事業実施に踏み切った。第
二期整備案では、鉄道駅から離れた北端部（八条通側）沿道につい て、住宅と集客核、バスターミナル形成等の拠点開発を計画したが、 市全体の土地利用及び交通計画に反映されるに至らなかった。

表 1 社会実験及び歩行者専用道路の大規模整備における主な費用分担 (単位：百万円） 注6)

\begin{tabular}{|l|c|c|c|}
\hline & $\begin{array}{c}\text { 社会実験 } \\
(1969 \text { 年 })\end{array}$ & $\begin{array}{c}\text { 第一期整備 } \\
(1972 \text { 年 })\end{array}$ & $\begin{array}{c}\text { 再整備 } \\
(1998 \sim 2002 \text { 年 })\end{array}$ \\
\hline 市 & 2 & 30 & 約 1,800 \\
\hline 商店街 & 6 & 30 & 約 300 (自主事業費) \\
\hline その他 & $\begin{array}{c}2 \\
\text { (スポンサーの } \\
\text { 寄付を含む) }\end{array}$ & 0 & $\begin{array}{c}\text { 約 } 1,170 \\
\text { (国の街路事業及び電 } \\
\text { 線共同溝整備事業 } \\
\text { を含む) }\end{array}$ \\
\hline 計 & 10 & 60 & 約 3,270 \\
\hline
\end{tabular}

\section{4. 第一期整備以降の変遷}

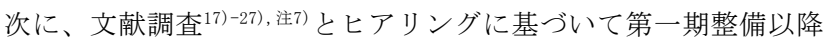
の変遷を整理し、I〜V期の5期に区分した注8)（図4）。

第一期整備完成から第二次石油ショック翌年までの、歩行者専用 道路の活用が進んだ1972〜80年を第 I 期、マネジメント上の問題が 蓄積した $1980 〜 86$ 年を第 II 期、買物公園の再整備の検討が本格化し 実施決定する1986〜 97年を第 III期、再整備の着工から完成までの 1997〜2003年を第IV 期、再整備後の活用期を第 V 期とした。

また、各期のマネジメント主体の歩行者専用道路に対する問題意 識を把握するために、沿道再開発、周辺交通及び歩行者専用道路の デザインという項目別に、買物公園の整備計画案注7)の変遷を図5に まとめた。更に街路空間に関する文献28)-30)に基づく歩行者専用道路

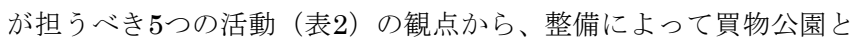
周辺空間の持つ特徴がどのように変遷したか整理し、図5の下部に 追記した。

表2＼cjkstart歩行者専用道路の担うべき活動と必要となる空間要素

\begin{tabular}{|l|l|}
\hline \multicolumn{1}{|c|}{ 活動のタイプ } & \multicolumn{1}{c|}{ 必要となる空間要素 } \\
\hline 必要活動 & 沿道建築物の入居テナントの多様性 \\
\hline 任意活動 (景観・回遊性) & 街路、沿道建築物のハード設備 \\
\hline 社会活動(滞留可能性) & $\begin{array}{l}\text { 沿道建築物の入居テナント（喫茶店等） } \\
\text { ファニチャー・植栽等 }\end{array}$ \\
\hline 言論・表現活動 & パフォーマンス・デモの開催可能性 \\
\hline ハレの活動 & 大型イベント、市場の開催可能性 \\
\hline
\end{tabular}

\section{4-1 第一期整備後の歩行者専用道路の活用（第 I 期：1972 80年）}

第 I 期は企画委員会（1969～2013年現在）に加え、行政、商店街 等の民間事業者、市民代表を主体とした事業運営委員会（1973年発 足）により進められた(表3)。

表3第 I 期のマネジメント体制注9)

\begin{tabular}{|c|c|c|}
\hline 組織名 & 構成主体 & 検討内容 \\
\hline 企画委員会 & $\begin{array}{l}\text { 商店街振興組合、市、 } \\
\text { 商工会議所 }\end{array}$ & $\begin{array}{l}\text { 第一部会(総務、広報、調査) } \\
\text { 第二部会(管理、造成、再開発) } \\
\text { 第三部会(事業) }\end{array}$ \\
\hline 事業運営委員会 & $\begin{array}{l}\text { 市民代表、商店会、 } \\
\text { 買物 公園事務局、 } \\
\text { 市・道路管理課、 } \\
\text { 関係行政機関 }\end{array}$ & $\begin{array}{l}\text { 『平和通歩行者専用道路管理 } \\
\text { 要綱』の規定にもとづき、管理 } \\
\text { 運営の基本についての必要な } \\
\text { 事項を審議する。 }\end{array}$ \\
\hline
\end{tabular}




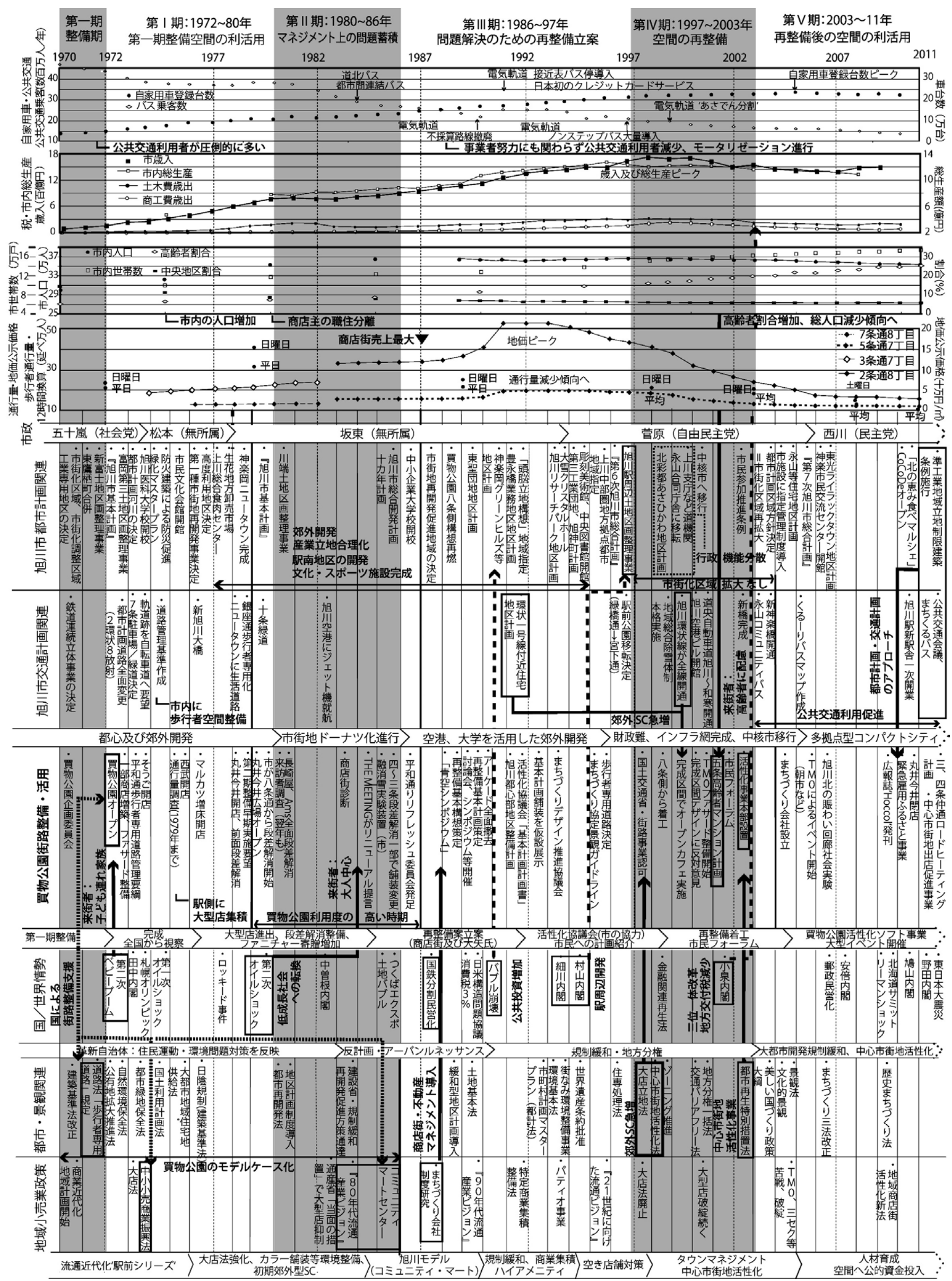

図 4 社会情勢、都市計画、交通計画等とマネジメントの変遷 
(1)合意形成

(1)第二期整備に向けた調整の難航

企画委員会が中心に、第二期整備に向けて沿道商店主及び土地所 有者に対する権利調整を試みた。しかし、第一期整備のみでも通行 量が増加した事や、第一期整備及び管理運営の負担を原因として、 中小商店主や土地所有者らは消極的であり、合意形成は難航した。 (2)管理運営規則の決定

新たに設置された事業運営委員会は、市民による歩行者専用道路 の利活用の経過を見た上で『平和通歩行者専用道路管理要綱』を設 け、具体的な実施主体や内容を規定した。要綱では市民の広場とし てふさわしい利用が目指され、公共団体の広報活動や市民による文 化的な催物を主な利活用目的とする一方、沿道商店主による営利目 的の利用を規制した。ただし、例外的に企画委員会、公共団体、教 育関連及び社会福祉関係の団体、市と共催する事業団体が主催の場 合や旭川の風物詩である物品を扱う市場や屋台を許可するとした。
(2)資金を含めた事業計画

(1)道路整備

第一期整備後、駅側を中心に複数の大型店が集積し、それら大型 店が店舗前面の段差や公開空地の整備を負担した。

一方で、行政も買物公園を契機に制度化された道路交通法や中小 小売商業振興法関連の支援を財源に、北側商店街の段差解消整備を 行った（図 $4:$ 第 I 期）

(2)管理運営

冬季の除雪費用及び電気代の $3 / 4$ は市が負担する一方、商店街は植 管理、清掃、電気代の $1 / 4$ につい、買物公園による事業収入(屋台 による収入、遊具使用料、ショーケース使用料)や市補助金からの 支出を含む約 2 千万円/年を負担するとした注7)。

(3)土地利用計画・交通計画との関係性

買物公園に続く市内の歩行者環境の向上のために、街路数本を歩行 者専用化した。しかし、有効なモータリゼーション緩和策は採られ

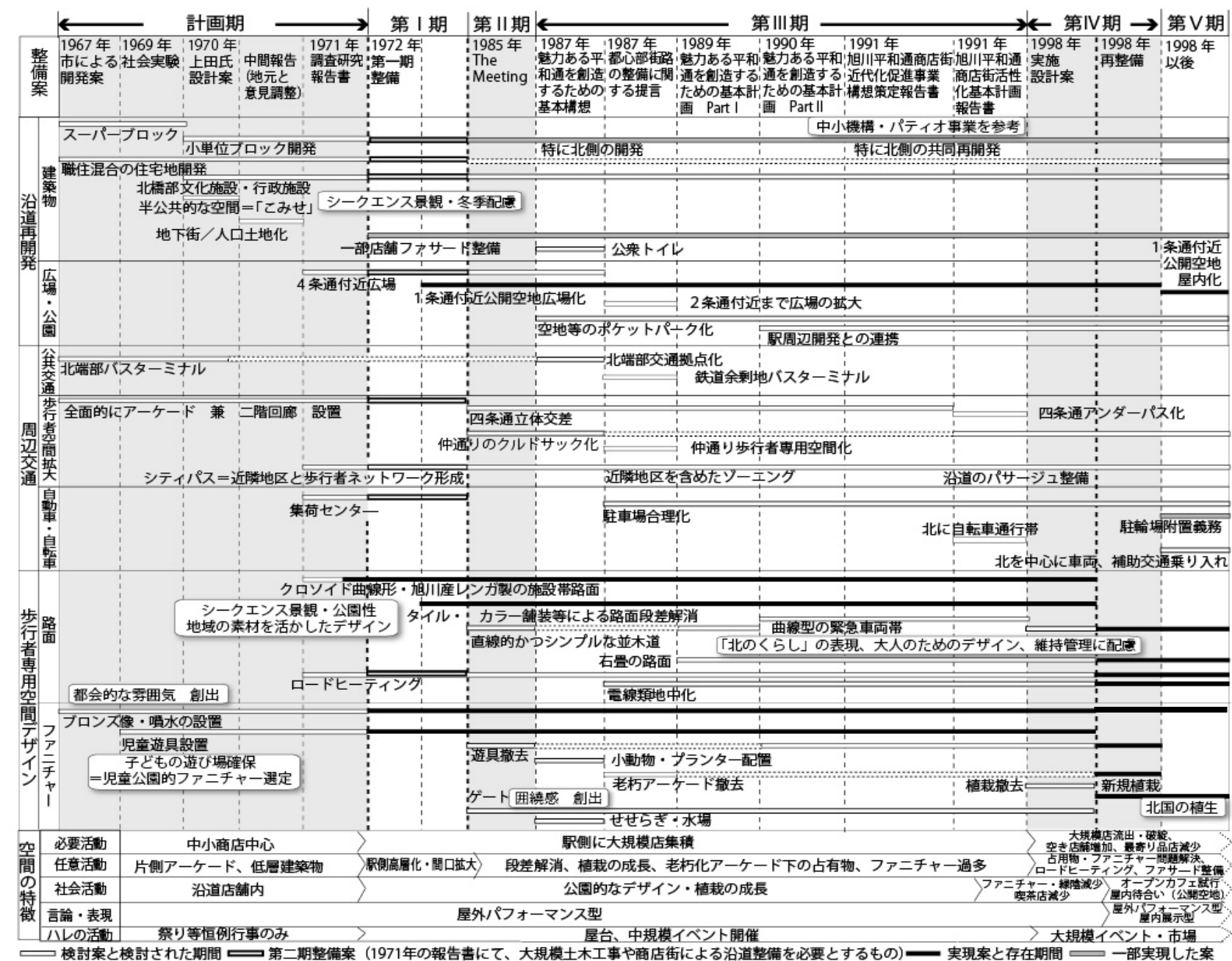

図 5 買物公園の整備計画案の変遷と買物公園及び周辺空間の特徵の変遷

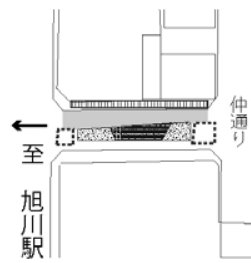

施設帯(植栽) 施設帯 (フアール

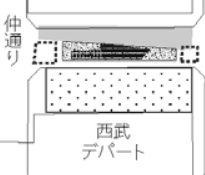

緊急車両帯 $y=$ 条通

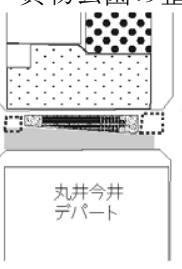

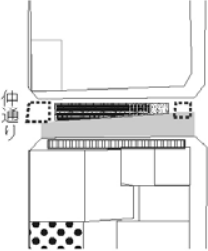

$\because \because \because$

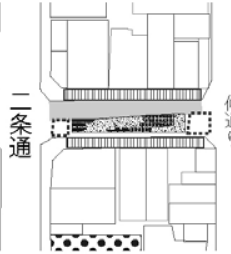

$\because \cdots 0$

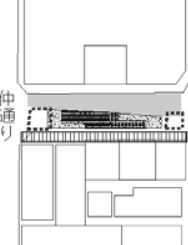

$\therefore \therefore$ 駐車場 (立体も含む)

放置自転車の多い場所

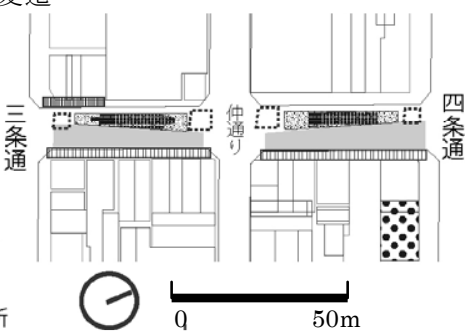

図 61980 年代における買物公園（一～四条通）の平面構成注 ${ }^{10)}$ 
ず、基幹公共交通であるバスの利用者も減少に転じた。

\section{4-2 マネジメント上の問題の蓄積（第 II 期 : 1980 86年）}

第 II 期では、オイルショックや少子化といった社会情勢の転換を 経た上で、第一期整備以来の中長期にわたるマネジメントの問題点 を見出し、それらの解決を迫られていたと言える。

(1)合意形成

(1)第二期整備案の見直し

商店街有志は、「The Meeting」と題した議論の機会を持ち、社 会情勢の変化を受けて、子ども連れ家族の来街を想定した当時の歩 行者専用道路のデザインについて問題提起した（図 4 : 第 II 期）。

(2)景観への問題意識

整備から 10 年以上経過する中で、商店主が既設アーケードの下 で行っていたあふれだしが歩行者専用道路の整備後もそのまま続き、 一部は拡大していた。また、市民参加の象徵として、寄贈品等が景 観的配慮もあまりないままに施設帯(図 6)に増設されることもあっ た。商店街有志は、このような景観の状況に対し問題意識を持った (平和通商店街振興組合へのヒアリングによる)。

(2)資金を含めた事業計画

商店街の売上げはピークであったが、地価の急激な上昇に伴い土 地所有者への課税額も上昇していたとみられる注11)。こうした経済 情勢の下でも資金調達は第 I 期と同様になされたが、前述の通り、 設置物や占有物が増えた分、維持管理の負担が増加していた ${ }^{2}$ 。

(3) 土地利用計画・交通計画との関係性

市が 80 年代以降、郊外拠点開発を本格化した結果、市街地のド 一ナツ化が進行した。そうした土地利用の変化から、さらなる公共 交通利用者の減少や買物公園の商店主の職住分離とそれに伴う商店 主同士のコミュニケーションの希薄化が徐々に進んだ注 11)。

\section{4-3 問題解決のための再整備計画立案（第正期:1986〜97 年）}

商店街有志と大矢二郎氏 (当時、東海大学教授) らが中心となり、 社会情勢への対応とマネジメント上の問題の解決を目的として第二 期整備案に替わる再整備案の検討が本格化した（図 4 : 第亚期）。

(1)合意形成

(1)活性化協議会の立ち上げ

商店街が主導し、再整備に向けた視察や商店街の実態調查を重政 た上で、上川支庁、商工会議所や当時郊外部を重点的に整備してい た市を巻き込み「活性化協議会」を立ち上げた。

(2)基本計画策定

同協議会は歩行者専用道路と商店街組織を共に再編することを目 指し、1991 年に「旭川平和通買物公園活性化基本計画報告書」（以 下、基本計画)を策定した。

基本計画の特色は次の 3 点である。まず、(1)シンプルな大人のた めの空間へと転換するために児童遊具を取り去る等、特徵を大きく 変化させる再設計案を提示した。但し、路面設計には曲線を描く施 設帯を取り入れる等、第一期整備と共通点を見いだせる部分もあっ た（図 5）。同時に、(2)街区毎に異なる施設帯のデザインを取り入 れたゾーン演出も見直し、代わりに買物公園沿道の建築用途につい て 3 区分のテーマを持たせた。また、(3)商店街にまちづくり会社等 の当時最新の地域小売業政策の動向を取り入れ、通行量が微増に留 まっていた北側沿道建築物について、中庭（パティオ）を付設する
店舗集団化を行うパティオ事業等の再開発を促進するとした。

基本計画策定には、市民代表が参加する他、シンポジウム開催や 路面のサンプル展示公開など、積極的な市民参加が図られた。

(2)資金を含めた事業計画

歩行者専用道路の維持管理に係る資金調達は、第 II 期の延長線上 であり、同様の方法で行われた。また、調査や報告書作成は各種助 成金を獲得する毎に行われた注 ${ }^{13)}$ 。

(3) 土地利用計画・交通計画との関係性

増加する自動車交通への対応策が、基本計画検討において、相対 する $2 つ の$ 観点から議論された。歩車共存道路の事例調査を行う一 方、北海道庁から歩行者空間の連続性確保の要請を受けて注 ${ }^{12)}$ 、交 通量の多い四条通交差点における歩行者の安全確保のために車道の アンダーパス化(図 5)を検討した。

\section{4-4 歩行者専用道路の再整備（第IV期: 1997 2003 年）}

再整備着工期にあたる第 $\mathrm{IV}$ 期では、市及び商店街は、大店立地法 や三位一体改革等の国の制度改革の影響を受けて、厳しい財政下に 置かれたが再整備を完成した(図 4 : 第IV期)。

(1)合意形成

実施設計について、(1)第一期整備の関係主体との協議がなかった こと、(2) 20 年以上親しまれた植樹やファニチャーが多数取り去られ たこと、(3)基本設計報告書以後から実施設計策定に至るプロセスの 不透明性について、市民に加え、一部商店主からも批判を受けた集11) (2)資金を含めた事業計画

1998年、再整備は国土交通省の街路事業の認可を受けて着工した （表1）。当時の地域小売業政策は、既存ストック活用やソフト事 業が盛んであったこともあり、関連予算を獲得できなかった。整備 は国の事業認可制度を活用できる範囲内に留まり、長年かけて策定 した基本計画の完全な実現には至らなかった。

その結果、基本計画に示されたよりも簡素かつ直線的なデザイン で 2003 年に完成した。沿道の再開発はあまり進まなかったが、官 民恊㗢で(1)ロードヒーティング設置と公開空地の屋内化、(2)まちづ くり協定と合わせた景観ガイドライン作成、(3)一部店舗の突出物件 解消とファサード整備、(4)アーケードと占有物の撤去、及び5)電線 地中化を実施した(図 5)。

(3)土地利用計画・交通計画との関係性

買物公園の大型店が郊外に流出するなど、ドーナツ化した都市構 造の下で大店立地法の影響を大きく受けた。このため、商店街は郊 外大型店への対抗策として自動車交通を重視し駐車場の充実に力を 入れている ${ }^{31)}$ 。

\section{4-5 再整備後の歩行者専用道路の活用（第 $\mathrm{V}$ 期: 2003 12 年）}

第 $\mathrm{V}$ 期には、都心の賑わい低下が顕在化し、買物公園を核とした 382ha（図1）の区域を対象にした「旭川市中心市街地活性化基本計 画」事業（以下、中活事業）が承認された(図 4 : 第 $\mathrm{V}$ 期)。

(1)合意形成

(1)沿道不動産の用途再編の試み

まちづくり会社を設立し、北側における沿道不動産のテナントミ ックス事業等が進められたが、数件に留まり、依然として空店舗は 増加傾向にある ${ }^{32)}$ 。

(2)TMOによる歩行者専用道路活用支援 


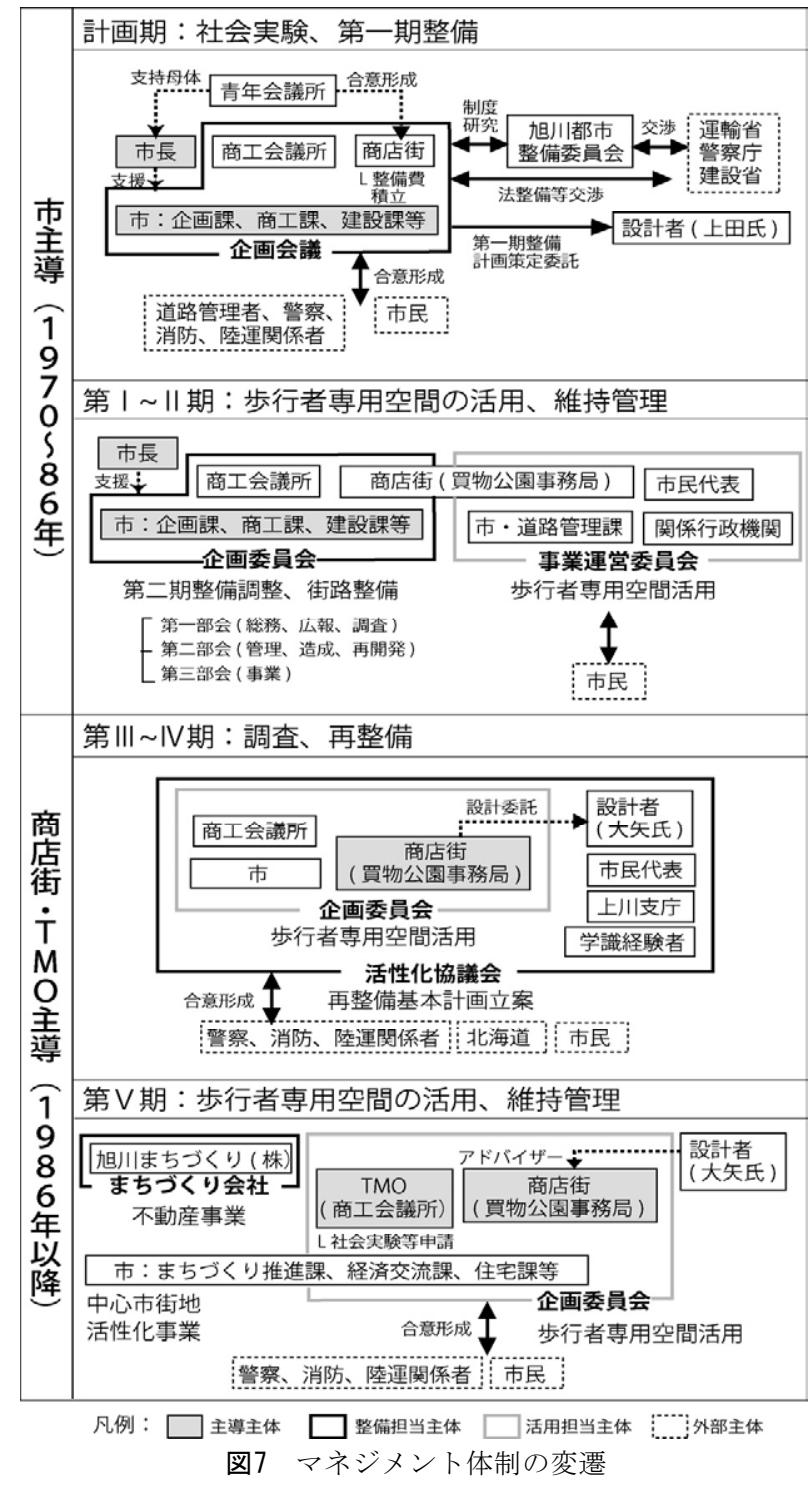

商工会議所がTMOとして、大型イベントが開催可能となった再整 備後の歩行者専用道路の活用を推進した。商店街も広報誌やホーム ページの充実により市民への情報発信の充実を図った。

\section{(2)資金を含めた事業計画}

再整備後、ファニチャー数が減少したことにより、維持管理に係 る総コストは減少傾向にある注 ${ }^{12)}$ 。また、再整備した空間の活用に ついて中活事業関連支援策の適用が可能になった。

(3) 土地利用計画・交通計画との関係性

(1)市内の土地利用及び交通の見直し

2000 年代以降、市の総人口は減少傾向に転じ、2006年策定の「第 七次旭川市総合計画」は、多拠点型のコンパクトシティ政策へと転換 した。中活事業にも反映され、市街地循環バスの運行等の公共交通 の強化を目指寸と共に、高齢者居住法に基づく街なか居住、既成市 街地内の公営住宅建替え、そして駅周辺開発「北彩都あさひかわ事 業」に伴う鉄道駅南側への新規住宅の立地誘導等により中心市街地 の居住人口を確保する事業を進めた。但し、総合計画では多拠点の 日常生活圈の利便性を向上するとしており、高齢者を慣れ親しんだ 近隣コミュニティから如何に住替え誘導するかという点では、未だ
積極策を打ち出すには至っていないと言える注14)。

(2)駅直結の商業施設誘致

2012年にJR北海道が旭川駅に直結の延床面積 $42,760 \mathrm{~m}^{2}$ の商業施 設誘致を決定した ${ }^{33)}$ 。そのため、駅周辺開発による局所的な人口増 加と合わせて、鉄道駅の求心性が更に高まると予想される。

(3)補助交通の導入検討

商店街を中心に、補助交通導入や北側商店街への住宅用途の付加 による高齢者の利便性向上など、人口動態への対応を意識した将来 の整備に関するアイデアが提示され始めた。しかし、補助交通導入 には、現在の路面が車両荷重に耐える素材でないことや、抵抗感を 抱く市民や商店主の存在から、実現に向けた動きは活発でない ${ }^{34)}$ 。

\section{4-6 社会情勢の変化への対応からみたマネジメント変遷}

各期における社会情勢の変化への対応から見たマネジメントの変 遷をまとめると、その概要は、以下のように整理できる。

(1)第二次ベビーブーム後の子連れ来街者増加に対応した遊具設置 などの道路空間整備（第 I 期）、(2)オイルショック後の大規模ハー ド整備中心からの転換と計画の見直し（第 II 期）、(3)バブル経済に よる来街者の急増とバブル経済後の低下を経て、膨らんだ維持管理 経費と低成長に対応した再整備計画の立案（第III期）、(4)来訪者の 年代層の変化を受けた遊具撤去、郊外居住者の増加による商店街の 日常的利用の低下に伴う週末・祝祭日の大型イベントに適した街路 構成への再整備、自動車交通増加を受けた駐車場整備がなされた(第 IV 期) 。更に、(5)高齢化への対応策としての補助交通の導入や沿道 の住宅整備が検討されている（第 $\mathrm{V}$ 期）。

即ち、買物公園では社会情勢の変化への対応を歩行者専用道路の 空間デザインの変更を中心とするハード整備に主眼を置いてきたと 言える。そのため、歩行者専用道路の再整備費用の負担が膨らみ、 市行政と沿道商業事業者の負担増へと繋がることになったと言える。

\section{5. マネジメントの特徵・課題と留意点}

第 4 章では、各期における社会情勢の変化とマネジメントの対応 を時系列で整理した。そもそも歩行者専用道路は、多くの歩行者が 日常的に利用することによりその整備の意義や価值が維持される。 そのため、マネジメントでは、沿道の土地利用にも影響を受ける歩 行者の回遊行動の誘発や地区の賑わいの創出を共に進めていかなけ ればならない。そこで、本章では、「合意形成」「資金を含めた事業 計画」「土地利用計画・交通計画との関係性」の観点から、買物公園 のマネジメントの特徴、及び対応に難航してきた課題を整理し、得 られた知見から歩行者専用道路の持続的なマネジメントを検討する 上での留意点を考察することとする。

\section{5-1 合意形成}

(1)道路整備と連動した沿道の用途転換と再開発

(1)特徵・課題

市は、歩行者専用道路を先行して整備することで、沿道敷地の用 途転換や再開発が促進されることを狙った。また、計画期から現在 に至るまで、沿道の再開発について商店主や土地所有者と協議する 組織体制として企画委員会やまちづくり会社が整備されてきた（図 7）。しかしながら、買物公園の整備に伴う来街者の増加により、 再開発を進めなくとも存続が可能となる小売店が増え、来街者が増 え続けてきた1990年代前半 (第而期)までの期間において沿道敷地 
の一体的な整備が先送りになってきた。その後、歩行者通行量や地 価下落期に入ってしまい (図4の通行量・地価公示価格変化を参照)、 民間事業者を中心とした再開発の時期を逸してしまったと言える。

(2)留意点

上述の買物公園の課題は、道路整備の初期から沿道敷地の再開発 や建替えに対するインセンティブ付与や資金援助などの積極的な誘 導策を行政が取る必要性を示唆していると言える。また、交差点部 沿道等の重要拠点における開発誘導策を取ることによって、歩行者 専用道路と連動した再開発を誘導することも肝要であると言える。 (2)マネジメントの段階的変化に応じた参加とガイドライン

(1)特徵・課題

買物公園では道路空間の整備内容や活用方法を試行錯誤してきた 計画期及び第 I 期において、市民の様々なアイデアを直に波み上げ、 活用可能性を把握する過程を取り入れた。その上で、公共空間とし ての道路に相応しい路上での活動を規則で定め、比較的円滑にマネ ジメントしてきた。特に、企画委員会、もしくは市と共催の商業活 動や、旭川の風物詩となる路上での物品販売を受け入れ、賑わいを 創出しながら事業収入を得る方法を先駆的に導入してきた（前述 $4-1)$ 。

第IV期における再整備実施設計一の批判（前述4-4）は、このよう な直接的な市民参加の機会がこの時期に不足していたことに起因寸 るものであったと言える。一方、買物公園の維持管理及び活用が本 格化する第 II 期では、市民からのファニチャー設置等の要望や提案 に対し、一定の基準を設けなかったことが景観問題(前述4-2)の一因 ともなった。

(2)留意点

以上の課題を踏まえ、行政は計画から供用開始までの時期では、 利用促進や利活用についての積極的な市民参加の機会づくりに配虑 することが肝要であり、公共空間としての道路の維持管理について は、地域の特性を踏まえた活用規則を策定するなど、地域が安定的 にマネジメントできる仕組みを確立する必要があると言える。

また、利活用が進むと様々な沿道設置物が増加する傾向にあるた め、秩序ある道路景観・沿道景観の維持に配慮したデザインガイド ラインの策定も合わせて行うなどの措置も必要である。

\section{5-2資金を含めた事業計画}

(1)自主資金の確保

(1)特徵・課題

市と商店街の各予算及び歩行者専用道路での事業収入から主に資 金調達されてきたが、第一期整備及び維持管理に係る費用や上昇分 の固定資産税等を負担した沿道の中小の商業事業者は経済的に苦し い立場となった(前述 4-1、4-2)。そのため、第 4 章で示したように 適用可能な国の補助金を財源とした事業が増え、その依存度が高ま った結果、補助金の要件を満たすために買物公園固有の課題へ柔軟 に対応し難くなり、課題対応に困難をきたしたと考えられる。

(2)留意点

買物公園も 1970 年代初頭の整備期には既に都心部が衰退傾向に あったが、道路整備の負担金は 3-2 で述べたように沿道の民間地権 者も負担した。一般に、歩行者専用道路の整備を伴う都心部の活性 化を目指寸場合、沿道の民間事業者は既に衰退傾向にあると考えら れ、買物公園の整備当初の官民の資金分担がその後に及ぼした影響
を考えると、当初から行政が道路整備の初期投資を負担し、沿道の 民間事業者や地権者に対しては経営改善や再開発等の整備を含め た事業の役割分担と資金負担の考え方が求められると言える。

また、維持管理と活用期においては、事業収入等からの積立など、 将来の修繕や再整備の備えへの配慮も求められる。

(2)長い線形に対応した事業計画

(1)特徴・課題

全長約 $1 \mathrm{~km}$ の買物公園は、鉄道駅に近い南側エリアと駅から遠い 北側エリアの間で、沿道の土地の潜在力が大きく異なり、それが沿 道地権者の投資意欲の差にも繋がり、建替えや土地の高度利用化の 進展の差にも繋がってきたと言える。こうした課題への対応策とし て、これまで、計画期においては、北側エリアでの職住混合の住宅 地開発、北端部バスターミナルの建設が検討され、第亚期において、 沿道を3区域に分節し近隣地区を含めたゾーニング設定による特色 ある整備といった方策が検討されてきた（図5参照）。

しかしながら、北側エリアの潜在力が相対的に低いことは予め予 測できたことであるにも関わらず、北側エリアの買物公園整備と連 動した再開発推進策の対応策の欠如や、敷地が細分化されているエ リアでの再開発や高度利用のための敷地統合の難しさからこれら の方策はいずれも実現されず、北側エリアの沿道土地の低利用の改 善は未着手のままである。

(2)留意点

以上の課題を踏まえると、歩行者専用道路の整備においては、歩 行者の回遊行動を想定した延長距離の設定に十分配慮する必要が あると言える。また、全長 $1 \mathrm{~km}$ に及ぶ買物公園のような比較的長距 離の歩行者専用道路整備にあたっては、全体を適切な距離ごとに分 節し、分節した各区域の立地条件に応じた拠点開発や交通アクセス の改善等の方策を伴うマネジメントが求められると言える。

\section{5-3 土地利用計画・交通計画との関係性}

(1)特徵・課題

買物公園はモータリゼーションの進行に対する問題意識から、全 国に先駆けて街なかを歩いて過ごす環境整備に取り組んだが、その 考え方が市の土地利用計画・交通計画に反映されないまま、主たる マネジメント業務が沿道の民間活力に委ねられてきた。その結果、 地区内の関係者だけの努力ではまかなえない中心市街地の空洞化 と一層のモータリゼーションを防げず、むしろ、増加する自動車交 通に歩行者専用道路を順応させる方策を取らざるを得なくなった。 (2)留意点

買物公園に限らず、一般に都心部の歩行者専用道路の整備は沿道 民間主体の活性化に焦点が当てられ、都心部の環境整備の枠組みの 中だけで捉えられがちだが、買物公園での課題が示すように、市全 体の土地利用計画や交通計画の中で、常に位置付けられ、配慮され る必要がある。

\section{6. おわりに}

本論文では、買物公園におけるマネジメントの変遷と特徵、課題 を整理してきたが、道路整備と沿道開発の双方が連動することで歩 行者専用道路の役割や意義が維持される。上記の留意点を行政と民 間のそれぞれの役割として整理すると、行政の果たす役割は、(1)道 路整備と沿道再開発の資金負担と役割の明確化、(2)整備する適正距 
離の設定と距離に応じた開発誘導、(3)沿道再開発・建替え事業の誘 導方策、(4)整備から維持管理の段階に応じた仕組みやガイドライン ら゙くり、(5)市全域の土地利用計画・交通計画における位置づけとの 整合を取り続けること、に整理できる。

また、沿道の商業事業者を中心とした民間の役割としては、(1)再 開発と用途転換、(2)持続的な経営改善、(3)道路を活用した活発なイ ベント等の企画・実施、(4)将来の再整備に対応する長期的な資金計 画に基づく積立て、に整理できる。

更に、買物公園では主としてマネジメント組織のみが道路空間の 維持管理を担ってきたが、清掃や植栽の管理等のへ参加を一般市民 のボランティアや地元企業に呼び掛けるなどし、市民や企業の幅広 い協力を得ていくことが、マネジメント組織の負担軽減にもつなが り、一般市民との関係強化にもつながると考えられる。

特に旭川市のような地方都市で、歩行者専用道路のマネジメント の方法を確立させることは、今後の地方都市の都心部の活性化につ ながる歩行者空間の整備を進めていく上で重要であり、今後は、現 在の買物公園の利用実態やマネジメント組織の実態を明らかにす る中から、マネジメント組織の将来展望を検討する必要がある。

\section{謝辞}

調査にご協力いただきました東海大学名誉教授大矢二郎先生はじめ 社団法人旭川ウェルビーイングコンソーシアム、平和通・三和商店 街振興組合関係者の方々、旭川市役所担当者の方々、そして、本論 文作成にてアドバイスをいただきました横浜国立大学大学院都市イ ノベーション研究院教授中村文彦先生に対し、感謝の意を表します。

注

注 1)国土地理院地図閲覽サービス http://watchizu.gsi.go.jp/を用いて作成。

注 2)第 3 章については、参考文献 5 を参照。

注 3)石脇亮,中野恒明:旭川市平和通り買物公園の成り立ちに関寸る研究,

http://www.sawadalab.se.shibaura-it.ac.jp/にて公開。

注 4)2012 年ゼンリン住宅地図をもとに作成。

注 5) 参考文献 15 にて財団法人都市調査会:旭川市都市再開発構想および平和 通買物公園設計に関する調查研究報告書, 1971 の存在と内容が言及されて いる。

注 6)社会実験費について参考文献 15、第一期整備費については 1973 年に作 成された旭川市資料に基づく。再整備費は旭川市から提供された整備に係 る年度別工種内訳及び合計額の資料をもとに、国の街路事業及び電線共同 溝整備事業における補助率を用い算出した。また、同市土木部へのヒアリ ングの結果より、商店街については自主事業費の負担額を掲載した。

注 7)旭川市より (1)平和通買物公園の概要, 1985、大矢二郎氏より以下の資料を 提供いただき参照した：(2)商店街有志が作成した THE MEETING,1985、 (3)平和通リフレッシュ委員会:魅力ある平和通を創造するための基本構 想,1987、(4)旭川都心部街路空間整備検討会:都心部街路の整備に関する提 言 一歩行者圈の確立に向けて-,1987、(5)旭川平和通商店街振興組合,旭川平 和通三和商店街振興組合, 旭川平和通リフレッシュ委員会: 魅力ある平和通 を創造するための基本計画 PART1,1989、(6)旭川平和通商店街振興組合, 旭川平和通三和商店街振興組合,旭川平和通リフレッシュ委員会:魅力ある 平和通を創造するための基本計画 PART II , 1990、(7)旭川平和通商店街振 興組合:旭川平和通商店街近代化促進事業構想策定報告書,1991、8旭川平 和通買物公園活性化協議会: 旭川平和通買物公園活性化基本計画報告 書,1991、(9)旭川市役所:平和通（買物公園）整備計画 施設デザイン検討 資料,2000、(10旭川市役所:平成 9 年度平和通買物公園実施設計, 1997

注 8)地価は国土交通省地価公示・都道府県地価調查

http://www.land.mlit.go.jp/landPrice/AriaServlet?MOD $=0 \& T Y P=0$ 参照。 注 9)『平和通歩行者専用道路管理要綱』より抜粋内容を表に編集。

注 10)1983 年の地図を基に作図し、参考文献 20 掲載の写真及び、旭川市よ り提供された記録写真から整備および利用状況を把握し追記した。
注 11)沿道商店主へのヒアリングに基づく。

注 12)平和通商店街振興組合へのヒアリングに基づく。

注 13)大矢二郎氏へのヒアリングに基づく。

注 14)旭川市の都市計画課、駅周辺開発課、土木建設課及びまちづくり推進課

の担当者に対してヒアリングを行った。

\section{参考文献}

1)今野博:まちづくりと歩行者空間-豊かな都市空間の創造をめざして,鹿島出 版会, 1980

2)Klaus Uhlig: Pedestrian areas: from malls to complete networks,Architectural Book Pub.Co,1979

3)Roberto Brambilla,Gianni Longo: For pedestrians only: planning, design, and management of traffic-free zones, Whitney Library of Design, 1977

4)高島聡,高橋賢一,平井健三:都市開発における歩行者空間の体系化とその系 譜-ストック化の限界性,公共空間の設えとマネージメント手法に着目して, 交通工学,Vol.33,No.1,pp.36-45,1998

5) 山口晋: 歩行者天国をめぐる管理の動き, 地理科学 Vol.60,No.3, pp.232-233,2005

6)森田翔, 出口敦:滞留行為の優位性に着目した歩行者天国に関する研究： 福岡市西新商店街を対象として,日本建築学会研究報告.九州支部.3,計画系 No.48,pp.465-468,2009

7) 上田篤:"買物公園"基本設計ノート,建築文化,319,pp.119-124,1972

8)若竹馨,松信泰輔,島峰隆,伊藤洋,横田武美,星輝男,松信隆也:ショッピングモ ール（普及版）第3部「イセザキモールの世界」,地域科学研究会, 1982

9)東海林孝男,小林英嗣:都市基盤事業と連動した都心域のエリアマネジメト の検討(札幌市駅前通地下歩行空間) : 成熟社会の都市再編計画論その 8 , 日 本建築学会大会学術講演梗概集. F-1, 都市計画, 建築経済・住宅問題,pp. 239-242,2007

10)長聡子,出口敦:エリアマネジメント組織による公共空間活用の仕組みに関 する研究, 日本建築学会大会学術講演梗概集. F-1, 都市計画, 建築経済・ 住宅問題, pp.179-180,2008

11)横山弘:<論説>旭川市の都市再開発について,弘前大学教育学部地理学研究 室,No.14,pp.1-5,1978

12)谷口綾子:北海道の都市における中心市街地活性化を目的とした歩行者モ ールの現状と課題,土木計画学研究・講演集,2002

13)佐々木悟: 中心市街地商店街の活性化と買い物の利便性:旭川市中心市街地 「平和通り買い物公園商店街」来街者アンケートを通して,旭川大学紀 要,Vol.62,pp.1-30,2006

14)旭川市企画室:伸びゆく大旭川:まちづくりの方向,旭川市, 1965

15)五十嵐広三,高橋芳郎: 人間都市復権,大成出版社, 1973

16)扇谷正造:レッツ・ラブ運動の展開:新・地方の時代 TBS ブリタニカ, 1982 17)旭川市総務局総務部総務課:旭川市統計書,旭川市,1972-2012

18)旭川平和通買物公園企画委員会:続・買物公園ものがたり，旭川平和通買物 公園企画委員会, 1977

19)旭川平和通買物公園企画委員会:続・続・買物公園ものがたり, 旭川平和通 買物公園企画委員会 1982

20)旭川市企画部:旭川市総合開発計画一人間都市をめざして,旭川市,1973

21)旭川市:旭川市基本計画-信頼と連帯による希望都市を目指して,旭川 市, 1979

22)旭川市:旭川市新総合開発計画-希望と活力が大雪山連峰にこだまする躍

動都市を目指して,旭川市, 1986

23)旭川市:第 6 次旭川市総合計画-水と緑に輝く北の拠点 - 旭川, 旭川 市, 1997

24)旭川市:第 7 次旭川市総合計画-人が輝く北の文化のかおるまち,旭川 市, 2006

25)旭川市:平成 24 年度版 ・旭川の都市計画概要,旭川市, 2012

26)石田頼房:日本近現代都市計画の展開-1868 2003,自治体研究社,2004 27)石原武政:地域小売商業政策の展開,経済産業研究所 BBL,2011

28)Paulhans Peters: 人間のための都市,鹿島出版会, 1978

29)Jan Gehl:建築のあいだのアクティビティ,鹿島出版会,2011

30)材野博司:庭園から都市ヘ-シークエンスの日本,鹿島出版会, 1997

31 北海道新聞, 1995 年 2 月 15 日

32)旭川市総合政策部:旭川市中心市街地活性化基本計画,旭川市,2011

33)北海道経済11月号,p.72,2012

34 )北海道新聞, 2009 年 2 月 24 日 